\title{
Bioremoval of Heavy Metals by the Native Strain Aspergillus niger
}

\section{ISSN: 2637-7659}

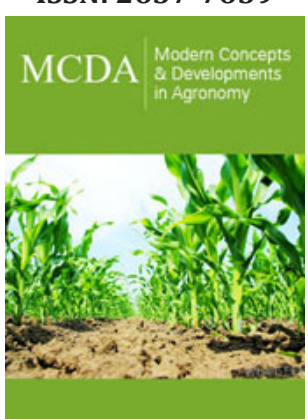

*Corresponding author: Juan F Cárdenas González, Unidad Academica Multidisciplinaria Zona Media, Centro de Investigación y Extensión de la Zona MediaEl Balandrán, Universidad Autonoma de San Luis Potosi, Carretera Rioverde-San Ciro Km. 4.5, Colonia Puente del Carmen, C.P. 79617, Rioverde, S.L.P., Mexico

Submission: 䤉 October 01, 2019

Published: 觜October 18, 2019

Volume 5 - Issue 2

How to cite this article: Juan F C G, Ismael A R, Adriana S R P, Víctor M M J, María G M Z, et al. Bioremoval of Heavy Metals by the Native Strain Aspergillus niger. Mod Concep Dev Agrono.5(2). MCDA.000610.2019. DOI: 10.31031/MCDA.2019.05.000610

Copyright@ Juan F Cárdenas González, This article is distributed under the terms of the Creative Commons Attribution 4.0 International License, which permits unrestricted use and redistribution provided that the original author and source are credited.
Juan F Cárdenas González ${ }^{1 *}$, Ismael Acosta Rodríguez ${ }^{2}$, Adriana S Rodríguez Pérez ${ }^{1}$, Víctor M Martínez Juárez ${ }^{3}$, María G Moctezuma Zarate ${ }^{2}$, Nancy C Pacheco Castillo $^{2}$ and Alejandra Muñoz Morales ${ }^{1}$

${ }^{1}$ Unidad Academica Multidisciplinaria Zona Media, Centro de Investigación y Extensión de la Zona Media-El Balandrán, Universidad Autonoma de San Luis Potosi, Mexico

${ }^{2}$ Laboratorio de Micología Experimental, Facultad de Ciencias Químicas, Universidad Autónoma de San Luis Potosí, México

${ }^{3}$ Universidad Autonoma del Estado de Hidalgo, Instituto de Ciencias Agronomicas, Unidad Academica de Medicina Veterinaria, Méxic ${ }^{\text {co }}$

\begin{abstract}
The objective of this work was study the resistance and removal capacity of heavy metals by the fungi Aspergillus niger. We analyzed the resistance to some heavy metals by dry weight and plate: the fungi it grows in 2000 ppm of zinc, lead, and mercury, 1200 and 1000ppm of arsenic (III) and (VI), 800ppm of fluor and cobalt and least in cadmium (400ppm). With respect to their potential of removal of heavy metals, this removal efficiently zinc, $(100 \%)$, mercury (83.2\%), fluor (83\%), cobalt (71.4\%), fairly silver (48\%) and copper (37\%). We determine the optimal characteristics for lead, mercury, cobalt and zinc removal in dry cells. The ideal conditions for the removal of $100 \mathrm{mg} / \mathrm{L}$ of the heavy metals $\mathrm{Cr}(\mathrm{VI})$ were $28{ }^{\circ} \mathrm{C}$, pH between $4.0-5.5,100 \mathrm{ppm}$ of heavy metal, and $5 \mathrm{~g}$ of fungal biomass.
\end{abstract}

Keywords: Biosorption; Heavy metals; Bioremediation; Microorganisms; Aspergillus niger

\section{Introduction}

Heavy metals are ubiquitous contaminants that have accompanied to the man from the earliest ancient times, and unlike other environmental pollutants, heavy metals are chemical elements that man does not create or destroy. The role that man plays in the environmental presence of metals is: to introduce into the environment these elements as a result of different human activities, and on the other hand, to alter the chemical or biochemical form in which they are. Metals are naturally subject to biogeochemical cycles that determine their presence and concentration in different natural environments such as soil, groundwater and surface, air and living beings. Human intervention can greatly modify the concentration of metals in these environments and facilitate their distribution from the mineral reserves in which metals are naturally confined [1]. From the toxicological point of view, metals often present a marked multiplicity of toxic effects. The specific chemical species of the metal strongly influences these effects, as well as the toxicokinetic variables of absorption, distribution and excretion. The toxicological significance of heavy metals, taking into account their ubiquity, the extent of their industrial and domestic uses, as well as their environmental persistence, which has to be evaluated based on the characteristics of the chemical compound of which the metal is part, and which determine its mobility environmental and its bioavailability [2]. In Mexico, there are reports of the presence of heavy metals in rivers, lakes, crops, soils and air urban areas, as well as in coastal environments, and marine ecosystems, where the accumulation of toxic metals in fish and shellfish tissues of human consumption $[3,4]$, and mining is one of the main causes of environmental pollution by heavy metals, mainly due to the inadequate management of their called "jales mineros".

Pollution problems in states such as Zacatecas, San Luis Potosi, Guerrero and Sonora [46]. Reports indicate that in Mexico there could be million tonnes of "jales" at national level, 
of which they are still unknown the conditions and their potential to affect the environment $[1,7]$. The most common example is the soil contamination, which occur during the extraction of gold and silver, commonly made by amalgamation with mercury and cyanidation. In neither case, there is a total recovery of the compounds or added elements, so it is common to find them in the process residues (mining sludges) in soluble form [1,4,7], so that, the "Jales" contain a great quantity of residual metals that derive from a process of extraction that is not $100 \%$ efficient. The maximum permissible limits of these metals for soils and waters in Mexico, established in the NOM-147-SEMARNAT/SSA1-2004 [8] and NOM-001-SEMARNAT-1996 [9], respectively. In humans, heavy metals can become very toxic when introduced into the organism. At high concentrations, these can cause: skin rashes, stomach upset (ulcers), respiratory problems, weakening of the immune system, damage to the kidneys and liver, hypertension, alteration of genetic material, cancer, neurological disorders and even Death [10].

Despite of existing legislation on disposal and waste management, it is clear that the problem persists. The foregoing, together with the waste from mining, aggravates the situation of the contamination by heavy metals in Mexico. Differents public institutions have developed investigations to establish the magnitude of this problem and have proposed strategies to contribute to the solution of the same, focusing on the use of biological alternatives that result in a lower alteration of the environment, specifically through the use of microorganisms for the removal of heavy metals or biosorption [11]. There are many reports of the isolation of resistant microorganisms to heavy metals and the use of microbial biomass for the removal of heavy metals, from industrial wastewater and/or contaminated water: the resistance and removal of Rhizopus stolonifier to lead, cadmium, copper and zinc [11], the tolerance and removal mechanisms of heavy metals (lead, cadmium, and chromium), by the fungus Pleurotus ostreatus
HAAS [12], Bacillus megaterium nickel resistance and her capacity of removal [13], heavy metal susceptibility and removal potential (mercury, copper, and lead), of Rhodotorula mucilaginosa [14], the resistance of Alcaligenes sp. BAPb.1 to lead (II), copper (II), zinc (II), nickel (II) and chromium (VI), and his capacity for removal lead (II) [15], the isolation and identification of fungi and yeast resistant to lead (II) [16], the resistance and removal of chromium (VI) by $A$. niger [17], the removal of diferent heavy metals by A. niger [18], the removal of lead, cadmium, copper and nickel for by A. niger [19], the removal of aluminium, iron, lead, and zinc by $A$. niger during the bioleaching process [20], and the removal of copper (II), manganese (II), Zinc (II) niquel (II), iron (III), lead (II), and cadmium (II) by immobilized cells of $A$. niger [21], with highly satisfactory results. This chapter reports the removal of different heavy metal in an aqueous solution by a strain of $A$. niger which is highly resistant to some heavy metals.

\section{Material and Methods}

\section{Microorganism and heavy metals resistant tests}

A fungal strain A. niger, was isolated from the polluted air in a fuel station, near the Faculty of Chemical Science, UASLP (San Luis Potosi, Mexico) (Figure 1) [17], and this was used for the screening. The strain was grown on a Petri dish containing modified Lee's minimal medium (LMM) (with $0.25 \% \mathrm{KH}_{2} \mathrm{PO}_{4}, 0.20 \% \mathrm{MgSO}_{4}, 0.50 \%$ $\left(\mathrm{NH}_{4}\right)_{2} \mathrm{SO}_{4}, 0.50 \% \mathrm{NaCl}, 0.25 \%$ glucose, and $2 \%$ agar) supplemented with $500 \mathrm{mg} / \mathrm{L}$ of $\mathrm{K}_{2} \mathrm{CrO}_{4}$. The $\mathrm{pH}$ of the medium was adjusted and maintained at 5.3 with $100 \mathrm{mmol} / \mathrm{L}$ of citrate phosphate buffer. The plates were incubated at $28{ }^{\circ} \mathrm{C}$ for 7 days. Fungal cultures grown in thioglycolate broth were used as primary inoculums. Heavy metals-resistant tests of the isolated strain, the fungi A. niger, were performed on liquid LMM containing the appropriate nutritional requirements and different concentrations of heavy metals (as salt), and the dry weight was determined.

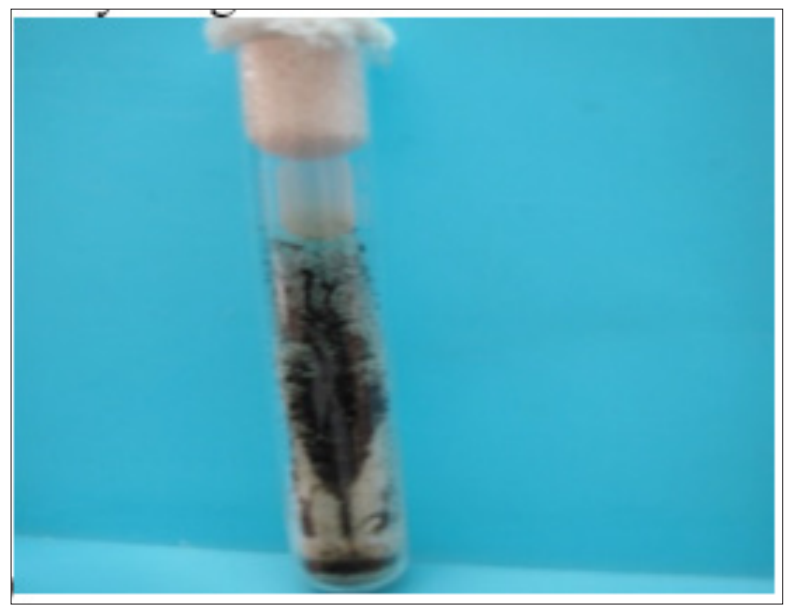

a

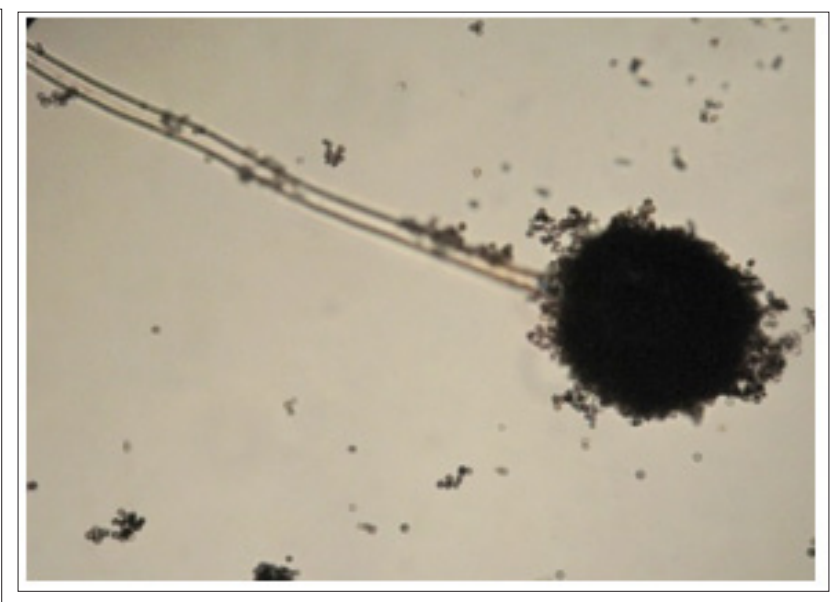

b

Figure 1: (a) Macroscopic and (b) microscopic morphology of the fungus Aspergillus niger.

\section{Plate resistant testing}

Petri dishes were prepared with Sabouaud Dextrose Agar, added with different salts of heavy metals. The prepared plates were inoculated with $1 \times 10^{6}$ spores/mL, and uniformly spread throughout the dishes, and incubated at $28{ }^{\circ} \mathrm{C}$ for 7 days, and the growth of the plates was compare with a control. 


\section{Obtaining the fungal biomass}

The fungus was grown at $28{ }^{\circ} \mathrm{C}$ in a stirred and aerated liquid media containing thioglycolate broth at a concentration of $8 \mathrm{~g} / \mathrm{L}$ $(\mathrm{p} / \mathrm{v})$. After 7 days of incubation, the cells were recovered by centrifugation (3000rpm, 10min) and washed three times in the same conditions with deionized water, and subsequently, it was dried $\left(80^{\circ} \mathrm{C}, 24 \mathrm{~h}\right)$ in an oven.

\section{Preparation of iron oxide-coated biomass}

$80 \mathrm{~mL}$ of $2 \mathrm{M} \mathrm{Fe}\left(\mathrm{NO}_{3}\right)_{3} \cdot 9 \mathrm{H}_{2} \mathrm{O}$ was prepared and $1.0 \mathrm{~mL}$ of $10 \mathrm{M}$ $\mathrm{NaOH}$ was added to this solution and mixed thoroughly. $20 \mathrm{~g}$ of the yeast biomass powder was taken in a porcelain pot, a mixture of iron oxide and $\mathrm{NaOH}$ solution was added to the porcelain pot and homogenized; kept in an oven for $3 \mathrm{~h}$ at $80^{\circ} \mathrm{C}$. After $3 \mathrm{~h}$ the oven temperature was raised to $110{ }^{\circ} \mathrm{C}$ and continued for $24 \mathrm{~h}$. The coated biomass powder was separated by crushing with mortar and pestle [22].

\section{Biosorption tests for lead (II), mercury (II), cobalt (II) and zinc (II) by dry fungal cells}

Solutions of lead (II), mercury (II), cobalt (II), and zinc (II) for analysis were prepared by diluting $1 \mathrm{~g} / \mathrm{L}$ of stock metal solution. The concentration range of heavy metals solutions was 100$1000 \mathrm{mg} / \mathrm{L}$. The $\mathrm{pH}$ of each solution was adjusted to the required value by adding $1 \mathrm{M} \mathrm{H}_{2} \mathrm{SO}_{4}$ solution before mixing with the fungus. The biosorption of the metals by fungal dry cells was determined at different concentrations of $100 \mathrm{~mL}$ heavy metal solution, with $1 \mathrm{~g}$ of fungal biomass, at $100 \mathrm{rpm}$, and the sample was filtered. The filtrate containing the residual concentration of heavy metals was determined. The supernatantwas analyzed for residual heavy metals at different times after a contact period. For the determination of the effects of $\mathrm{pH}$ and temperature, different solutions ( $\mathrm{pH} 3-8$,), temperatures $\left(28^{\circ} \mathrm{C}, 37^{\circ} \mathrm{C}\right.$, and $\left.45^{\circ} \mathrm{C}\right)$, heavy metals concentrations
(100-1000mg/L), fungal biomass concentration $(1,2,3,4$ and $5 \mathrm{~g} / 100 \mathrm{~mL}$ ) were respectively used.

Moreover, biosorption to the contaminated water was examined. Six Erlenmeyer glass flasks which contain $5 \mathrm{~g}$ of fungal biomass and $95 \mathrm{~mL}$ of water [263mg/L of lead (II), $183 \mathrm{mg} / \mathrm{L}$ of mercury (II), and $250 \mathrm{mg} / \mathrm{L}$ of cobalt (II)], from the farmland of the "Tanque Tenorio" (which is southeast of the city, in the municipality of Soledad de Graciano Sánchez, S.L.P., México, and is a catchment lagoon of wastewater, of which $60 \%$ is from urban origin and $40 \%$ of industrial origin, (it should be noted that the industrial zone of San Luis Potosí has more than 520 companies, among which are the mining-metallurgists, textiles and chemicals) (SEDECO 2015), and they were incubated during 7 days, stirred at 100rpm, and filtered in Whatman filter paper No. 1. The concentration of lead (II), mercury (II), and zinc (II) of the filtrate were analyzed by dithyzone method [23] (Greenberg 1992), and cobalt (II) by methyl isobutyl ketone method [24].

\section{Removal by different heavy metals by using dry fungus}

Solutions of heavy metals for analysis were prepared by diluting $1 \mathrm{~g} / \mathrm{L}$ of stock metal solution. The concentration range of heavy metals solutions was $1-100 \mathrm{mg} / \mathrm{L}$. The $\mathrm{pH}$ of each solution was adjusted to the required value by adding $1 \mathrm{M} \mathrm{H}_{2} \mathrm{SO}_{4}$ solution before mixing with the fungus microorganism. The biosorption of the metals by fungal dry cells was determined at different concentrations of $100 \mathrm{~mL}$ heavy metal solution, with $1 \mathrm{~g}$ of fungal biomass, at $100 \mathrm{rpm}$, and the sample was filtered. The filtrate containing the residual concentration of heavy metal was determined: chromium (VI) spectrophotometrically with dhyphenylcarbazide, zinc (II), lead (II), mercury (II), cadmium (II), with dithizone [23] cobalt (II) by methyl isobutyl ketone [24], fluor (I) by specific ion, and copper (II), arsenic (III), arsenic (V), and silver (I), by atomic absorption [25].

\section{Result and Discussion}

\section{Isolation and identification of a fungal strain resistant to heavy metals}

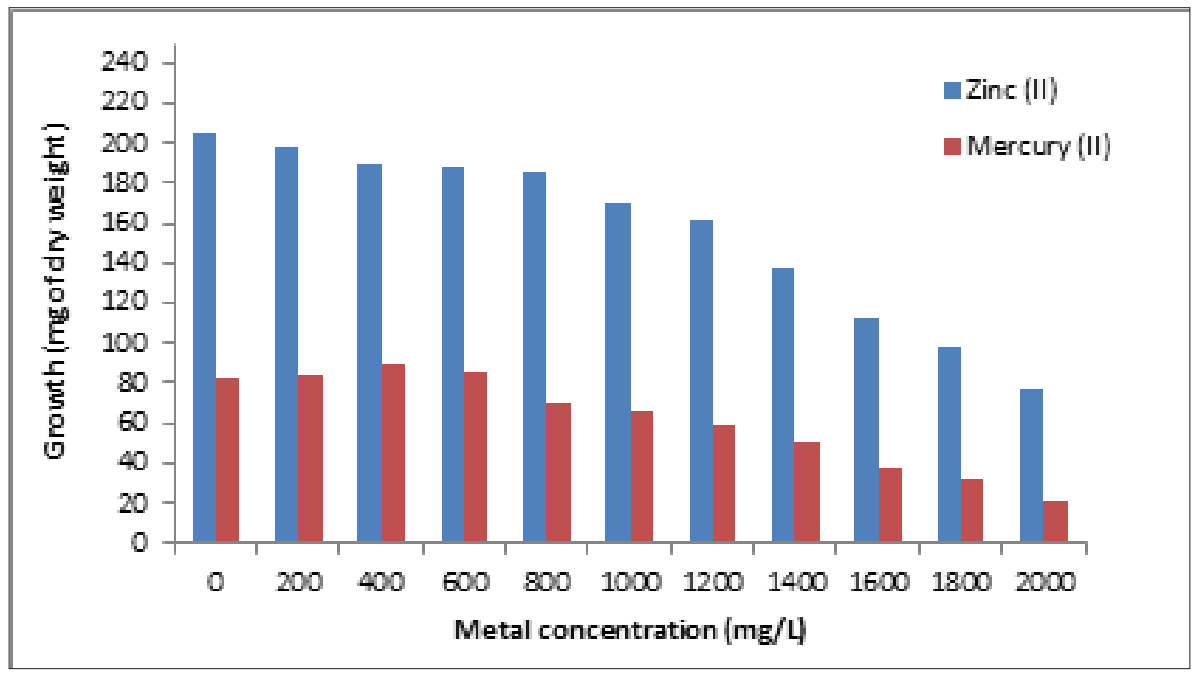

Figure 2: Growth in dry weight of Aspergillus niger with different heavy metals concentration. $1 \times 10^{6} \mathrm{spores} / \mathrm{mL}$. $28^{\circ} \mathrm{C}, 7$ days of incubation. 100rpm. 
The fungus was grown on the LMM agar plates containing different concentrations of heavy metals and the largest colony of the fungus was isolated. Colonies isolated grew rapidly within

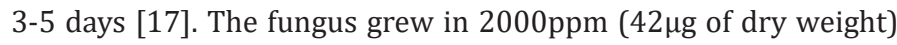
of chromium (VI), and present very good adsorption capacity of chromium (VI) in different conditions (Table 1) [17], too, the strain grew on LMM supplemented with different concentrations of heavy metals, about $37.6 \%, 24.6 \%$, and $13.55 \%$, of Zinc (II), mercury (II), and lead (II), respectively, of growth relative to control without metal. (Figures $2 \& 3$ ), and, therefore, probably is resistant to the metals, although, grew a $16 \%$ with $1.4 \mathrm{~g} / \mathrm{L}$ of Arsenic (III), and is very sensitive to cobalt (II) $(12.8 \%$ with $600 \mathrm{mg} / \mathrm{L})$. On the other hand, in plate resistant testing, the fungus grow in $2000 \mathrm{mg} / \mathrm{L}$ of zinc (II), lead (II), mercury (II) and chromium (VI), 1200g/L of As (III), $600 \mathrm{mg} / \mathrm{L}$ of cobalt (II) and $400 \mathrm{mg} / \mathrm{L}$ of cadmium (II) (Table 2).

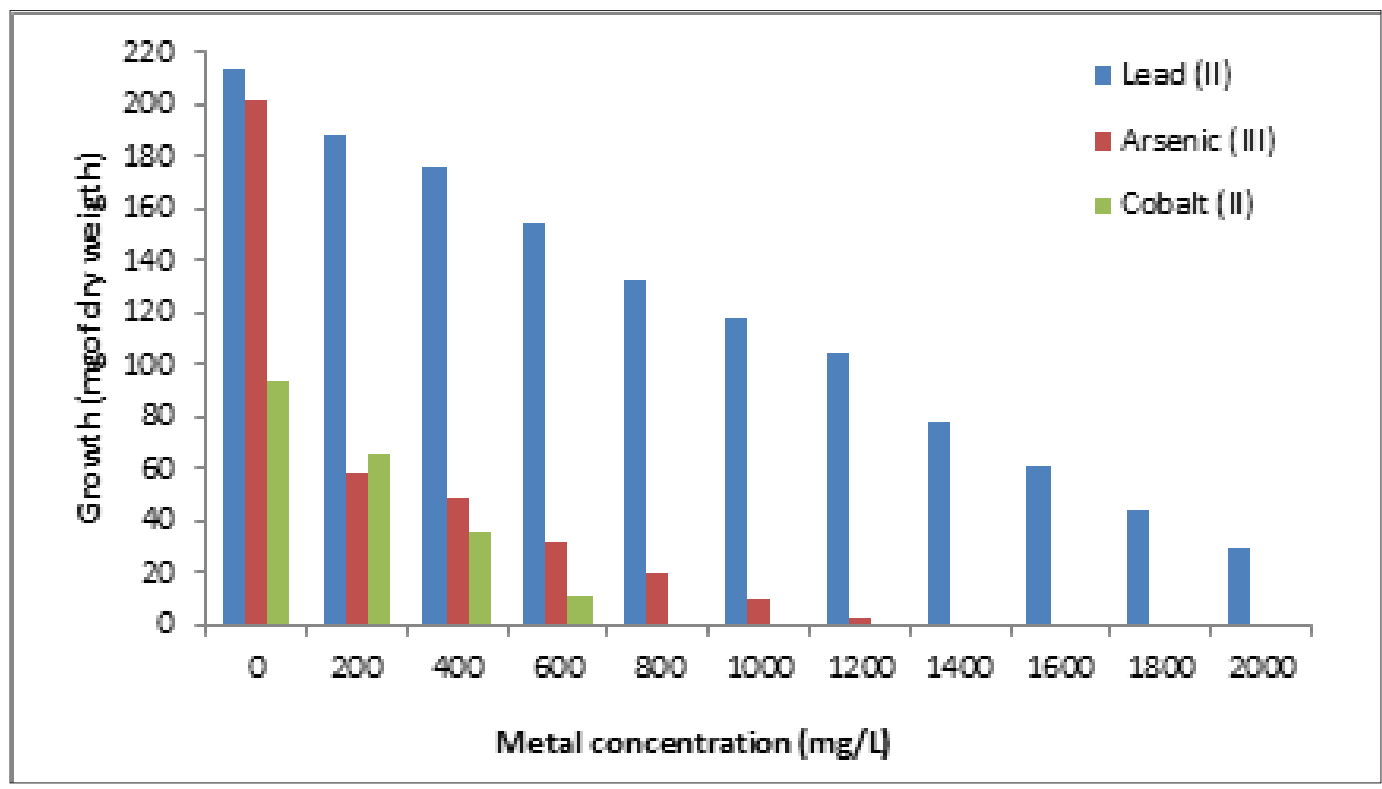

Figure 3: Growth in dry weight of Aspergillus niger with different heavy metals concentration. $1 \mathrm{x} 10^{6} \mathrm{spores} / \mathrm{mL}$. $28^{\circ} \mathrm{C}, 7$ days of incubation. 100rpm.

Table 1: Bioadsorption capacity of chromium (VI) in different conditions by Aspergillus niger*

\begin{tabular}{|c|c|}
\hline Fungus Conditions & Removal Capacity \\
\hline 1. Dry cells biomass & $\begin{array}{l}\text { a. } 50 \mathrm{mg} / \mathrm{L}, 30 \text { minutes, } \mathrm{pH} 1.0,28^{\circ} \mathrm{C}, 1 \mathrm{~g} \text { of fungal biomass. } 100 \mathrm{rpm} \text {. } \\
\text { b. } 1 \mathrm{~g} / \mathrm{L}, 180 \text { minutes, } \mathrm{pH} 1.0,28^{\circ} \mathrm{C}, 1 \mathrm{~g} \text { of fungal biomass. } 100 \mathrm{rpm} \text {. } \\
\text { c. } 1 \mathrm{~g} / \mathrm{L}, 13 \text { minutes, } \mathrm{pH} 1.0,60^{\circ} \mathrm{C}, 1 \mathrm{~g} \text { of fungal biomass. } 100 \mathrm{rpm} \text {. }\end{array}$ \\
\hline $\begin{array}{l}\text { Bioremediation in } \\
\text { industrial wastes }\end{array}$ & $\begin{array}{c}\text { a. } 71 \% \text { of water }(400 \mathrm{mg} / \mathrm{L} \text { water }), 7 \text { days, } \\
\mathrm{pH} 7.6,28^{\circ} \mathrm{C}, 5 \mathrm{~g} \text { of fungal biomass. } 100 \mathrm{rpm} \text {. } \\
\text { b. } 62 \% \text { of earth }(297 \mathrm{mg} / \mathrm{L}), 7 \text { days, } \\
\mathrm{pH} 8.2,28{ }^{\circ} \mathrm{C}, 5 \mathrm{~g} \text { of fungal biomass. } 100 \mathrm{rpm} \text {. }\end{array}$ \\
\hline 2. Living cells & $\begin{array}{l}\text { a. } 50 \mathrm{mg} / \mathrm{L}, 6 \text { days, } \mathrm{pH} 5.3,28^{\circ} \mathrm{C}, 100 \mathrm{rpm}, 8.3 \mathrm{mg} \text { of dry weight with fermentables carbon sources. There is reduction of } \mathrm{Cr}(\mathrm{VI}) \\
\text { to } \mathrm{Cr} \text { (III). }\end{array}$ \\
\hline $\begin{array}{l}\text { Bioremediation in } \\
\text { industrial wastes }\end{array}$ & $\begin{array}{l}\text { a. } 70 \% \text { of water ( } 50 \mathrm{mg} / \mathrm{L} \text { water), } 6 \text { days, } \mathrm{pH} 5.3,28{ }^{\circ} \mathrm{C}, 5 \times 106 \text { spores } / \mathrm{mL} .100 \mathrm{rpm} . \\
\text { b. } 50 \mathrm{mg} / \mathrm{g} \text { earth, } 6 \text { days, } \mathrm{PH} 8.53,28{ }^{\circ} \mathrm{C}, 5 \times 106 \text { spores } / \mathrm{mL} 100 \mathrm{rpm} .\end{array}$ \\
\hline 3. Resting cells & a. $80 \% 6 \mathrm{mg} / \mathrm{L}, 1$ hour, $\mathrm{pH} 7.0,37^{\circ} \mathrm{C}, 100 \mathrm{rpm}$. \\
\hline 4. Permeable cells & $\begin{array}{l}\text { a. } 68 \%, 6 \mathrm{mg} / \mathrm{L}, 8 \text { hours, } \mathrm{pH} .0,37^{\circ} \mathrm{C}, 100 \mathrm{rpm} \text {, } \\
\text { Triton X-100 (10mM). }\end{array}$ \\
\hline 5. Cellular free extract & a. $2 \mathrm{mg} / \mathrm{L}, 1$ hour, $\mathrm{pH} 7.0,37^{\circ} \mathrm{C}, 100 \mathrm{rpm}$. \\
\hline
\end{tabular}


Table 2: Growth in LMM in plate of Aspergillus niger with different heavy metals. $1 \times 106$ yeast $/ \mathrm{mL} .28{ }^{\circ} \mathrm{C}, 7$ days of incubation.

\begin{tabular}{|c|c|}
\hline Heavy Metal & $\begin{array}{c}\text { Growth } \\
\text { Heavy Metal Concentration } \\
\text { (mg/L) }\end{array}$ \\
\hline Zinc (II) & 2000 \\
\hline Lead (II) & 2000 \\
\hline Mercury (II) & 2000 \\
\hline Chromium (VI) & 2000 \\
\hline Arsenic (III) & 1200 \\
\hline Arsenic (V) & 1000 \\
\hline Copper & 1000 \\
\hline Silver & 1000 \\
\hline Fluor & 800 \\
\hline Cobalt & 600 \\
\hline Cadmium & 400 \\
\hline
\end{tabular}

Different microorganisms that are heavy metals resistant have been isolated from different contaminated sites: Screening the resistance to lead, cadmium, copper, and zinc of five fungal species isolated from soils: Emercilla quadrillineata, Aspergillus niger, Macrophomina phaseolina, Rhizopus stolonifier, and Aspergillus fumigatus, and the most resistant fungal species (1 $\mathrm{g} / \mathrm{L}$ of metals) was $R$. stolonifier followed by $M$. phaseolina which showed resistance with all the metals, while A. niger, A. fumigatus and Emercilla quadrillineata, were more sensitive to these heavy metals [11], the fungus Pleurotus ostreatus HAAS [12], grew very well in $500 \mathrm{mg} / \mathrm{L}$ of lead, and concentrations $30 \mathrm{mg} / \mathrm{L}$ of cadmium, $200 \mathrm{mg}$ / of chromium appeared to inhibit the growth of the fungus [12], Bacillus megaterium strain MNSH1-9K-1 tolerate up to 200ppm of each nickel and vanadium [13], Alcaligenes sp. BAPb.1, grow in presence of $1000 \mathrm{mg} / \mathrm{L}$ of lead (II), $600 \mathrm{mg} / \mathrm{L}$ of copper (II), $600 \mathrm{mg} / \mathrm{L}$ of zinc (II), $400 \mathrm{mg} / \mathrm{L}$ of nickel (II) and chromium(VI) [15], Penicillium sp., Trichoderma sp. and Alternaria sp, isolated from the farmland of the "Tanque Tenorio", growth with 500-2000 $\mathrm{mg} / \mathrm{L}$ of lead (II) [16], the resistance to $2000 \mathrm{mg} / \mathrm{L}$ by A. niger [17],
A. niger has been growth in the presence of different concentrations of metals like nickel, cobalt, iron, magnesium, and manganese [26], and the yeast Candida tropicalis, isolated from wastewater from industrial area of Sheikhupura, which it grown in $2.5 \mathrm{~g} / \mathrm{L}$ of cadmium (II), zinc (II) $(1,4 \mathrm{~g} / \mathrm{L})$ nickel (II) $(1 \mathrm{~g} / \mathrm{L})$, mercury (II) $(1.4 \mathrm{~g} / \mathrm{L})$, copper (II) $(1 \mathrm{~g} / \mathrm{L})$, chromium (VI) $(1.2 \mathrm{~g} / \mathrm{L})$, and lead (II) (1g/L) [27].

\section{Removal of Chromium (VI) by dry cells of Aspergillus niger}

Figure 4 shows the effect of incubation time and $\mathrm{pH}$ on the biosorption of $100 \mathrm{mg} / \mathrm{L}$ of zinc (II), lead (II), mercury (II), and Cobalt (II) by the biomass of $A$. niger. It was found that a higher removal, which is proportional to the biosorption, occurs at 24 hours and at a pH of 4.0 for lead (II), 5.0 for Cobalt (II), and 5.5 for mercury (II), and 165 minutes and pH of 5.0 for zinc (II). It was reported a time of two weeks and $\mathrm{pH} 7.0$, for M. phaseolina and $R$. stolonifier for the removal of lead, cadmium, copper and zinc, from soil [11], 10 days for the removal of lead, cadmium and chromium, in liquid culture with $P$. ostreatus HAAS [12], 48 hours for the removal of aluminium and nickel in liquid medium with $B$. megaterium [14], 30 minutes and $\mathrm{pH}$ of 5.0 for the removal of lead in liquid medium with Alcaligenes sp. BAPb.1 [15], 5 hours and $\mathrm{pH}$ of 5.0 for the removal of lead, cadmium, copper and nickel, with $A$. niger [19], four days of the elimination of $97.5 \%$ of copper, $88.2 \%$ of cadmium, $26 \%$ of lead, and $14.5 \%$ of zinc in dried soil residues with $A$. niger during the bioleaching process [20], 30 minutes and a pH 5.5, for the removal of copper (II) and cadmium (II) in batch systems by immobilized cells of $A$. niger [21], 120 minutes and $\mathrm{pH}$ 2.0, for the removal of $90 \%$ of chromium (VI) by NaOH pretreated $A$. niger biomass, and that heavy metal uptake by live $A$. niger biomass increases with increasing $\mathrm{pH}$ in the range 3-4 for cadmium (II) and pH 3-6 for zinc (II) at 6 hours [28]. The biosorption of heavy metal by fungi occurs as a result of ionic interaction and complex formation between metal ions and functional group present on the fungal cell surface [19]. These functional groups which may be involved in the biosorption of heavy metals include phosphate, carboxyl, amine and amide groups [29].

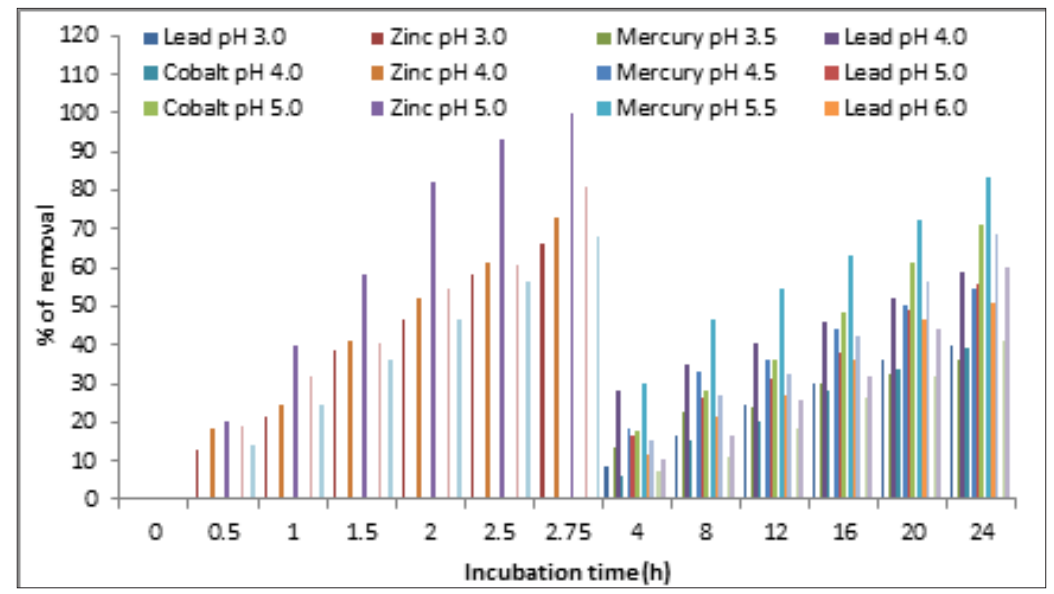

Figure 4: Effect of incubation time and $\mathrm{pH}$ on heavy metals removal by A. niger. 100mg/L of heavy metals, $100 \mathrm{rpm}, 28{ }^{\circ} \mathrm{C}$, and $1.0 \mathrm{~g}$ of fungal biomass. 


\section{Effect of the temperature}

In the Figure 5, we shown the effect of the temperature on heavy metals removal. The maximal adsorption capacity was found at $28{ }^{\circ} \mathrm{C}(100 \%, 83.2 \%$, and $59 \%)$ for zinc (II), mercury (II), and lead (II), respectively, while $37^{\circ} \mathrm{C}$ and $45^{\circ} \mathrm{C}$ for cobalt (II) (100\%), and this capacity decreased with temperatures higher than $28^{\circ} \mathrm{C}$. These results are similar to those reported for M. phaseolina and $R$. stolonifier for the removal of lead, cadmium, copper and zinc, from soil at room temperature [11], $30^{\circ} \mathrm{C}$ for the elimination of copper, cadmium, lead, and zinc in dried soil residues with $A$. niger during the bioleaching process [20], $25{ }^{\circ} \mathrm{C}$ for the removal of copper (II) and cadmium (II) in batch systems by immobilized cells of $A$. niger
[21], $30{ }^{\circ} \mathrm{C}$ for metal leaching from a spent catalyst by Alternaria alternata [30], $28{ }^{\circ} \mathrm{C}$ for the biosorption of arsenic (III) in aqueous solution by the modified fungal biomass of A. niger [31,32], and $28{ }^{\circ} \mathrm{C}$ for the bioremoval of arsenic (V) from aqueous solutions by chemically modified biomass of the fungi: Aspergillus flavus III, IV and V, Aspergillus fumigatus I-II, Paecilomyces sp., Cladosporium sp., and Mucor sp-1 and 2 [33]. The temperature of the adsorption medium could be important for energy-dependent mechanisms in metal biosorption by microorganisms. Energy-independent mechanisms are less likely to be affected by temperature since the process responsible for biosorption is largely physicochemical in nature [22].

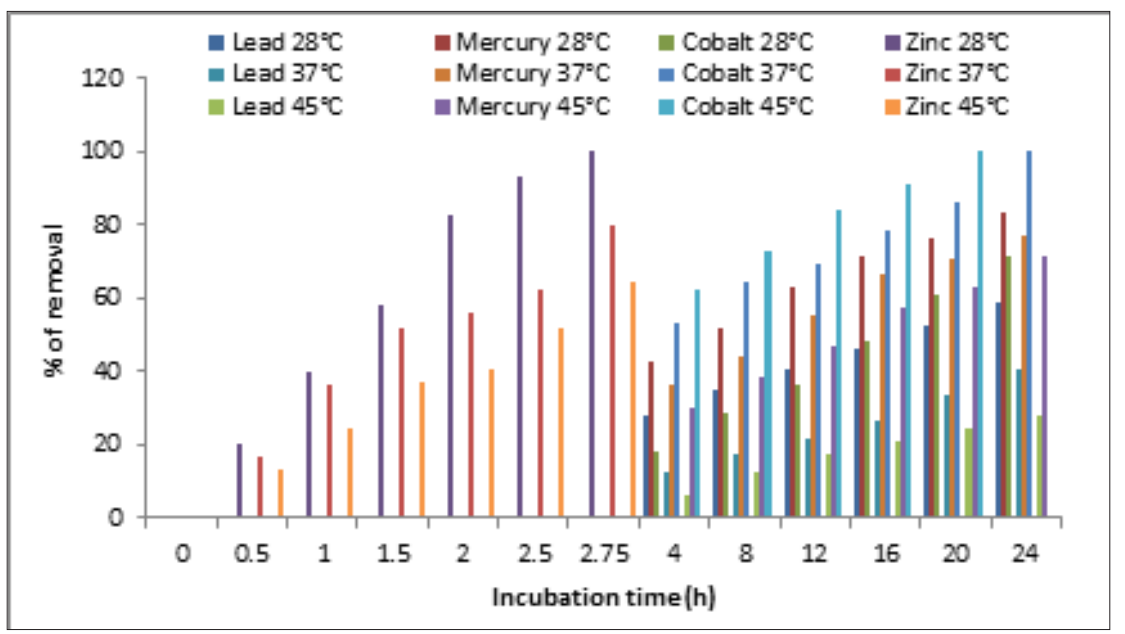

Figure 5: Effect of the temperature on heavy metals removal by A. niger. $100 \mathrm{mg} / \mathrm{L}$ of heavy metals, 100rpm, $\mathrm{pH}$ 4.0 for lead (II), 5.0 for zinc (II), and cobalt (II), and 5.5 for mercury (II), and $1.0 \mathrm{~g}$ of fungal biomass.

\section{Effect of the initial concentration of heavy metals}

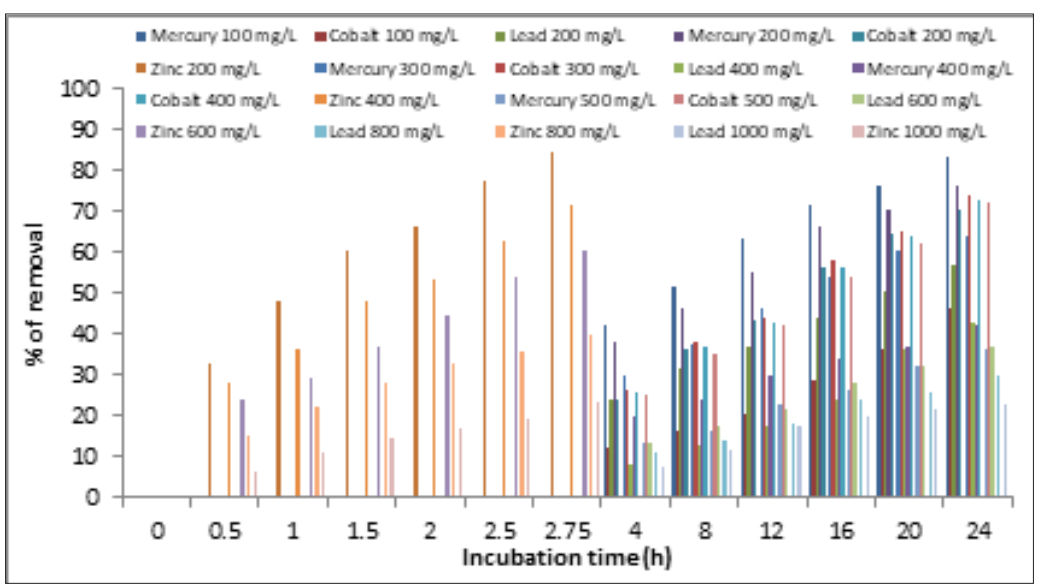

Figure 6: Effect of initial metal concentration on heavy metals removal by A. niger. $28^{\circ} \mathrm{C}, 100 \mathrm{rpm}, \mathrm{pH} 4.0$ for lead (II), 5.0 for zinc (II), and cobalt (II), and 5.5 for mercury (II), 100rpm, and $1 \mathrm{~g}$ of fungal biomass

The concentration influences the removal of the heavy metals; at lower concentration of the same, removal is faster (at 165 minutes and $24 \mathrm{~h}$ with $200 \mathrm{ppm}$, the removal is $84.5 \%, 76.3 \%$, $70.4 \%$, and $57.0 \%$, for zinc (II), mercury (II), cobalt (II), and lead (II), respectively) (Figure 6), and we observed that the percentage of adsorption decreased, when ions concentration increased. It have reported that optimum removal for Arsenic (V) and Arsenics (III) from wastewater by iron oxide-coated $A$. niger biomass can be achieved with a lower concentration of arsenic in solution [22], like for the biosorption of arsenic (III) in aqueous solution by the modified fungal biomass of A. niger [31], for C. neoformans the higher biosorption capacity was observed at low concentrations 
of metal ions $(0.2 \mathrm{mg} / \mathrm{L})$ [17], R. mucilaginosa for the removal of copper [14], the removal of chromium (VI) by A. niger isolated from the polluted air near the Faculty of Chemical Science, UASLP (San Luis Potosi, Mexico) [17], and Yarrowia strains isolated from sediments of mercury-polluted estuarine water [33]. On the other hand, the adsorbed amount of cadmium (II) and zinc (II) ions increases with the increasing initial metal ion concentrations in the range $25-250 \mathrm{mg} / \mathrm{L}$, for biosorption of heavy metals by live $A$. niger [28], which may be due to sorption at low concentrations happens, but at higher concentrations, possibly when positive positions were saturated, precipitation occurs (which is a slower process) [34].

\section{Effect of the initial concentration of biosorbent}

From the evaluation of the removal of $100 \mathrm{mg} / \mathrm{L}$ of heavy metals with different concentrations of biomass, it was found the higher the concentration of the latter, the removal of heavy metals is greater and faster. One gram of biomass with removal of $100 \%, 83.2 \%, 71.4 \%$ and 59\%, for zinc (II), mercury (II), cobalt (II), and lead (II), at 165 minutes and 24 hours, respectively, whereas $5 \mathrm{~g}$ removal time was smaller for the four heavy metals (Figure 7). These observations can be explained as the amount of added bioadsorbent determines the number of sites available for biosorption load of the ions or any metal contaminant [35]. Similar results have been reported for the removal of lead in liquid medium with Alcaligenes sp. BAPb.1, in which the biosorption rate increased rapidly from 28 to $90 \%$ with the biosorbent dosage that increased from 0.5 to $2.0 \mathrm{~g} / \mathrm{L}$ [15], for the removal of chromium (VI) by A. niger isolated from the polluted air [17], for the removal of copper (II) and cadmium (II) in batch systems by immobilized cells of $A$. niger [21].

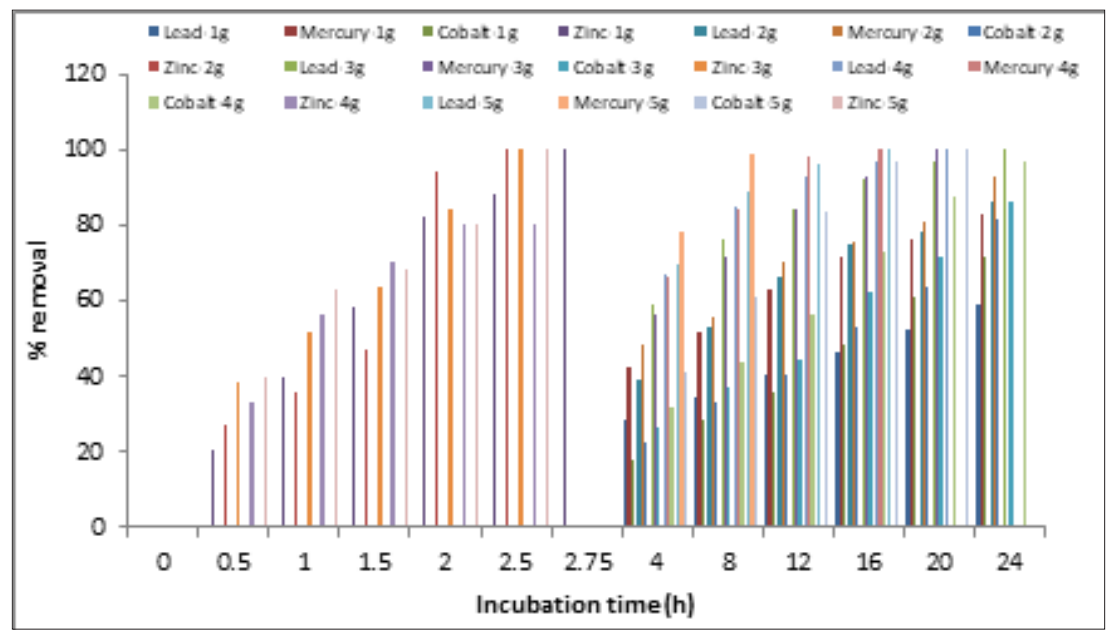

Figure 7: Effect of biomass concentration on heavy metals removal by A. niger.100rpm. pH 4.0 for lead (II), 5.0 for zinc (II), and cobalt (II), and 5.5 for mercury (II), $100 \mathrm{mg} / \mathrm{L}, 28{ }^{\circ} \mathrm{C}$.

It was observed as a general trend that there is an increase of the removal percentage with increase in adsorbent weight from 0.1 to $0.3 \mathrm{~g} / \mathrm{L}$ [21], for the biosorption of arsenic (III) in aqueous solution by 1, 2, 3, 4, and $5 \mathrm{~g}$ of modified fungal biomass of $A$. niger [31], in the biosorption of cobalt (II) ions from aqueous solution using rice straw, when the adsorbent dosage varied from 0.1 to $1.0 \mathrm{~g}$ [36], with pure and modified chitosan hydrogels from shrimp shell to carry out adsorption tests of copper in acid solution with increasing concentrations of the biosorbent $(1,2,3,4,4.5$ and 5g) [37]. However, uptake capacity of chromium (VI) by $\mathrm{NaOH}$ pretreated A. niger decreases with increased biomass dose [38], the zinc removal rate of the yeast Pichia kudriavzevii A16, was not significantly improved when the initial biomass concentration was raised from 0.05 to $1 \mathrm{~g} / \mathrm{L}$ [39], and for S. cerevisiae (BCRC23331), which the biosorption capacity of Ni (II) decreases with increasing adsorbent dose [40].

\section{Removal of heavy metals in industrial wastes with yeast biomass}

For analyze the possible use and the ability of A. niger biomass to removal lead (II), cobalt (II), and mercury (II), from wastewater, a removal assay was mounted in an aqueous solution in the presence of $5 \mathrm{~g}$ biomass, with $95 \mathrm{~mL}$ of nonsterile water contaminated (from "Tanque Tenorio"), with $263 \mathrm{mg} / \mathrm{L}$ of lead (II), $183 \mathrm{mg} / \mathrm{L}$ of mercury (II), and $250 \mathrm{mg} / \mathrm{L}$ of cobalt (II), at pH 5.0 (adjusted), $28{ }^{\circ} \mathrm{C}$ and stirring at $100 \mathrm{rpm}$. It was observed that at 7 days of incubation, $71 \%, 69 \%$, and $96.4 \%$, of the heavy metals present in the water contaminated were removal, respectively (Figure 8). The metal removal capability by the biomass of. A. niger is equal to or greater than the other biomasses that have been studied, like the removal of mercury, cadmium, an copper (4.79\%, 10.25\%, and 5.49\%, respectively), using $R$. mucilaginosa planktonic cells during 48 hours [14], the metal removals during two-step process using $A$. niger reached $84.3 \%, 84.4 \%, 25 \%$ and $14.4 \%$ for Copper, Cadmium, lead, and Zinc, respectively [20], the removal of cadmium (II) (95\%), lead (II) (88\%), iron (III) (70\%), copper (II) (60\%), nickel (II) (48.9\%), manganesum (II) (37.7\%), and zinc (II) (15.4\%, from industrial wastewater by in batch systems by immobilized cells of $A$. niger [21], the use of the extracellular media of A. alternata containing organic acids and siderophores for the metal leaching (vanadium, aluminum, silicius, molibdenum, magnesium, iron, nickel, arsenic, and chromium) [30], the removal of $67 \%$ of arsenic (III) from samples of groundwater contaminated with $1 \mathrm{mg} / \mathrm{L}$ from arsenic (III), coming from Zimapan, Hidalgo's state, México [31], 
the $99.35 \%$ removal of copper with pure and modified chitosan hydrogels from shrimp shell, from copper leachate [37], S. cerevisiae and Torulaspora delbrueckii decrease in 98.1\%, 83.0\%, 60.7\%, $60.5 \%$, and $54.2 \%$ for turbidity, sulphates, BOD, phosphates and COD, respectively, of the tannery effluent [40], C. tropicalis removal $40 \%$ of cadmium (II) from the wastewater after 6 days and was also able to remove $78 \%$ from the wastewater after 12 days [27], and $S$. cerevisiae "wild-type" (WT) parental strain BY4741, very efficient in removing magnesium (II), copper (II), cobalt (II) from synthetic effluents containing 1-2mM cations [41]. Industrial effluents often contain more than one type of metal ion; these may interfere in the removal/recovery of the metal ion of interest. Limited information about the effect of co-cations is available in the literature. The presence of other cations (co-cations) can affect the sorption of metal ions (primary cation) to the biomass and in some cases it may affect the removal efficiency [42].

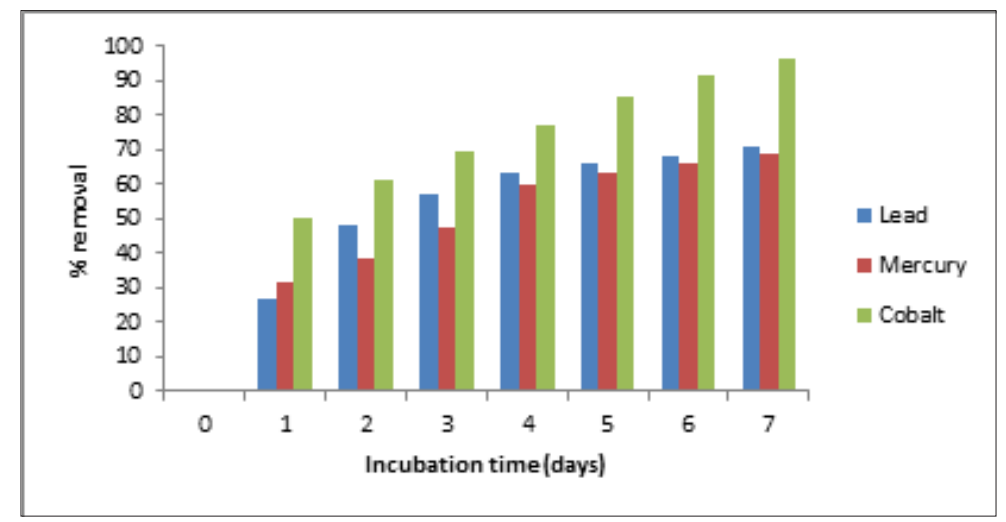

Figure 8: Removal of heavy metals from industrial wastes incubated with $5 \mathrm{~g}$ of fungal biomass, $100 \mathrm{rpm}, 28{ }^{\circ} \mathrm{C}$, $20 \mathrm{~g}$, and $95 \mathrm{~mL}$ of water contaminated with $263 \mathrm{mg} / \mathrm{L}$ of lead (II), $183 \mathrm{mg} / \mathrm{L}$ of mercury (II), and $250 \mathrm{mg} / \mathrm{L}$ of cobalt (II), at pH 5.0 (adjusted), $28^{\circ} \mathrm{C}$, and 100rpm.

Removal of different heavy metals by fungal biomass of A. niger

Finally, we analyzed the capacity of heavy metals removal by dry cell of the fungus. The results are shown in Table 3. The fungus removal efficiently most of the heavy metals analyzed: chromium (VI) and zinc (II) (100\%), mercury (II) (83.2\%), fluor (I) (83\%), and cobalt (II) (71.4\%), and lest efficiently silver (I) 48\% and copper
(37\%). Both living and dead fungal cells can be effective metal accumulators and there is evidence that some biomass-based cleanup processes are economically viable $[2,4]$. The tolerance of some fungal species to heavy metals, as well as the physiological response to them, have been also determined [2,11-13]. The removal of heavy metal ions, using fungi as biosorbents, was previously investigated $[2,4,17-22]$.

Table 3: Removal of different heavy metals by fungal biomass of $A$. niger. $28{ }^{\circ} \mathrm{C}$. $1 \mathrm{~g}$ of fungal biomass. $100 \mathrm{rpm}$. $24 \mathrm{~h}$.

\begin{tabular}{|c|c|c|c|}
\hline Heavy Metals & pH & Initial Concentration (mg/L) & \% Removal \\
\hline Chromium (VI) & 1 & 50 & $100^{*}$ \\
\hline Zinc (II) & 5 & 100 & 83.2 \\
\hline Mercury (II) & 5.5 & 100 & 83 \\
\hline Fluor (I) & 6 & 10 & 69.4 \\
\hline Cobalt (II) & 5 & 100 & $60^{* * *}$ \\
\hline Arsenic (V) & 6 & 1 & $66^{* * *}$ \\
\hline Arsenic (III) & 6 & 100 & 59 \\
\hline Lead (II) & 4 & 5 & 57 \\
\hline Cadmium (II) & 6 & 100 & 48 \\
\hline Silver (I) & 6 & 100 & 37 \\
\hline Copper (I) & 5 & & \\
\hline
\end{tabular}

Our results confirm the capacity of the microorganisms biomass for the removal of heavy metals with different effectivity, like bacteria, fungi, yeast, and algae-based microbiological decontamination of heavy metals contaminated soils of different places [2,4,5], M. phaseolina and R. stolonifier for the removal of for lead, cadmium, copper and zinc, from soil [11], removal of lead, 
cadmium and chromium, in liquid culture with $P$. ostreatus HAAS [12], the removal of lead, cadmium, copper and nickel, with A. niger [19], the elimination of copper, cadmium, lead, and zinc in dried soil residues with $A$. niger during the bioleaching process [20], the removal of copper (II) and cadmium (II) in batch systems by immobilized cells of $A$. niger [21], the removal of $90 \%$ of chromium (VI) by $\mathrm{NaOH}$ pretreated $A$. niger biomass, and that heavy metal uptake by live $A$. niger biomass for cadmium (II) and for zinc (II) [28], yeasts isolated from water, soil and plant environments [43], and other sudies with other species of A. niger [4,18,19,30,44-48].

\section{Conclusion}

We isolated a $A$. niger fungus, which grow with different heavy metals in LMM, and probably is resistant to the metals. In dead fungal biomass, removal efficiently different heavy metals [chromium (VI) and zinc (II) (100\%), mercury (II) (83.2\%), fluor (I) $(83 \%)]$ at different $\mathrm{pH}$ conditions [4.0 for lead (II), 5.0 for zinc (II), and cobalt (II), and 5.5 for mercury (II)], $28^{\circ} \mathrm{C}$, and $1 \mathrm{~g}$ of fungal biomass. Finally, these results suggest the potential applicability of A. niger for the remediation of heavy metals from polluted soils and waters.

\section{Conflict of Interest}

All the authors of this work transfer any and all rights in and to the paper including without limitation all copyrights to the 3 BIOTECH. All authors represents and warrants that the paper is original and that he/she is the author of the paper, except for material that is clearly identified as to its original source, with permission notices from the copyright owners where required. In the same way, all authors declare that there is no conflict of interest about this work, which is original.

\section{References}

1. Albert L (2015) Gestión de los productos químicos. En: México Tóxico. Albert LA, Jacott M (Eds.), 1a. XXI Siglo veintiuno editors Edn, México. 21-37.

2. Zaidi J, Pal A (2017) Review on heavy metal pollution in major lakes of India: Remediation through plants. Afr J Environ Sci Technol 11(6): 255265.

3. Mena MI, Bustamante GA, Vargas LS, Olvera HII, Méndez EJA (2017) Evaluación de la condición ecológica del río Zahuapan. Rev Int Contam Ambie 33(1): 7-19.

4. Covarrubias SA, Peña Cabriales JJ (2017) Contaminación ambiental por metales pesados en México: Problemática y estrategias de fitorremediación. Rev Int Contam Ambie 33: 7-21.

5. Cortés JEV, Mugica ÁV, González CMC, Carrillo GR, Martínez GM, et al. (2013) Natural revegetation of alkaline tailing heaps at Taxco, Guerrero, Mexico. Int J Phytoremediation 15(2): 127-141.

6. Ortíz OE, García NE, Juárez SL, Gómez CMA, García GE, et al. (2017) Lead exposure: pottery impact in Tlaxcala, México. Rev Int Contam Ambie 33(1): 57-64.

7. Ramos AYR, Siebe GCD (2006) Estrategia para identificar jales con potencial de riesgo ambiental en un distrito minero: estudio de caso en el Distrito de Guanajuato, México. Rev Mex Cienc Geol 23(1): 54-74.

8. SEMARNAT (2007) Norma Oficial Mexicana. NOM-147-SEMARNAT/ SSA1-2004. Que establece los criterios para determinar las concentraciones de remediación de suelos contaminados por arsénico, bario, berilio, cadmio, cromo hexavalente, mercurio, níquel, plata, plomo, selenio, talio y/o vanadio. Secretaría de Medio Ambiente, Recursos Naturales y Pesca. Diario Oficial de la Federación.

9. SEMARNAT (2003) Norma Oficial Mexicana NOM-001-SEMARNAT 1996. Que establece los límites máximos permisibles de contaminantes en las descargas de aguas residuales en aguas y bienes nacionales. Secretaría de Medio Ambiente, Recursos Naturales y Pesca. Diario Oficial de la Federación.

10. Nava RC, Méndez AM (2011) Efectos neurotóxicos de metales pesados (cadmio, plomo, arsénico y talio). Arch Neurocienc Mex 16(3): 140-147.

11. Fawzy EM, Abdel Motaal FF, El Zayat SA (2017) Biosorption of heavy metals onto different eco-friendly substrates. J Bioremediat Biodegrad 8(3): 1-7.

12. Yang S, Sun X, Shen Y, Chang Ch, Guo E, et al. (2017) Tolerance and removal mechanisms of heavy metals by the fungus Pleurotus ostreatus HAAS. Water Air Soil Pollut 228(130): 1-9.

13. Rivas CAM, Guatemala CME, Rojas ANG (2017) Effect of aluminum in Bacillus megaterium nickel resistance and removal capability. Mex J Biotechnol 2(2): 206-220.

14. Grujić S, Vasić S, Radojević I, Čomić L, Ostojić A (2017) Comparison of the Rhodotorula mucilaginosa biofilm and planktonic culture on heavy metal susceptibility and removal potential. Water Air Soil Pollut 228(73): 1-8.

15. Jin Y, Yu S, Teng Ch, Song T, Dong L, et al. (2017) Biosorption characteristic of Alcaligenes sp. BAPb.1 for removal of lead (II) from aqueous solution. 3 Biotech 7(2): 123

16. Moctezuma ZMG, Robles GA, Cárdenas GJF, Rodríguez PAS, Navarro CJF, et al. (2017) Isolation and identification of fungi and yeast resistant to Lead (II). J Multidiscip Eng Sci Technol 4(6): 5273-5278.

17. Acosta I, Rodríguez X, Gutiérrez C, Moctezuma MG (2004) Biosorption of chromium (VI) from aqueous solutions by fungal biomass. Bioinorg Chem Appl pp. 1-7.

18. Mukhopadhyay M, Noronha SB, Suraishkumar GK (2011) A review on experimental studies of biosorption of heavy metals by Aspergillus niger. Can J Chem Eng 89(4): 889-900.

19. Kapoor A, Viraraghavan T, Cullimore DR (1999) Removal of heavy metals using the fungus Aspergillus niger. Bioresource Technol 70(1): 95-104.

20. Yanga J, Wang Q, Luoa Q Wang Q Wud T (2009) Biosorption behavior of heavy metals in bioleaching process of MSWI fly ash by Aspergillus niger. Biochem Eng J 46(3): 294-299.

21. Tsekova K, Todorova D, Ganeva S (2010) Removal of heavy metals from industrial wastewater by free and immobilized cells of Aspergillus niger. Int Biodeterior Biodegradation 64(6): 447-451.

22. Pokhrel D, Viraraghavan $T$ (2006) Arsenic removal from an aqueous solution by a modified fungal biomass. Water Res 40(3): 549-552.

23. Greenberg AE, Clesceri LS, Eaton AD (1992) Standard methods for the examination of water and wastewater, $18^{\text {th }}$ edn. American Public Health Association, Washington, DC, USA, pp. 1-49.

24. Charlot G (1964) Colorimetric determination of elements. (trad. da $12^{\text {th }}$ edn. francesa) Elsevier Publishing Company-Amsterdam, Netherlands, p. 449.

25. SEDECO (2015) Directorio de empresas que operan en las zonas y parques industriales de la ciudad de San Luis Potosí. Secretaría de Desarrollo Económico. San Luis Potosí, México.

26. Valix M, Loon LO (2003) Adaptive tolerance behaviour of fungi in heavy metals. Mineral Eng 16(3): 193-198.

27. Rehman A, Anjum MS (2011) Multiple metal tolerance and biosorption of cadmium by Candida tropicalis isolated from industrial effluents: glutathione as detoxifying agent. Environ Monit Assess 174(1-4): 585595. 
28. Liu YG, Fan T, Zeng GM, Li X, Tong Q, et al. (2006) Removal of Cadmium and Zinc Ions from aqueous solution by living Aspergillus niger. Transactions of Nonferrous Metals Society of China 16(3): 681686.

29. Akhtar MN, Sastry KS, Mohan PM (1996) Mechanism of metal ion biosorption by fungal biomass. Biometals 9(1): 21-28.

30. Rojas ANG, Otamendi VJ, Gómez RM (2017) Metal leaching from a spent catalyst by Alternaria alternata. Mex J Biotechnol 2(2): 221-231.

31. Santos DEE, Cárdenas JF, Torre ME, Martínez VM, Rodríguez A, et al. (2017) Bioadsorción de Arsénico (III) en solución acuosa por la Biomasa Modificada de Aspergillus niger. Avan en Cienc e Ing 8(2). 1-10.

32. Cárdenas GJF, Acosta RI, Terán FY, Rodríguez PAS (2017) Bioremoval of arsenic (V) from aqueous solutions by chemically modified biomass. 3 Biotech 7 (3): (226).

33. Salvadori MR, Ando RA, Oller do Nascimento CA, Correa B (2014) Intracellular biosynthesis and removal of copper nanoparticles by dead biomass of yeast isolated from the wastewater of a mine in the Brazilian Amazonia. PLoS One 9(1): e87968.

34. Leyva RR (2010) Fundamentos de adsorción en sistemas liquido-sólido Situacion del arsenico en la Region Iberica e Iberoamericana. Posibles acciones articuladas e integradas para el abatimiento del arsenico en zonas aisladas. CYTED, Argentina Chapter 3, p. 43.

35. Kratochvil D, Volesky B (1998) Advances in the biosorption of heavy metals. Trends in Biotechnology 16(7): 291-300.

36. Swelam AA, Awad MB, Salem AMA, El Feky AS (2017) Biosorption of Cobalt (II) Ions from aqueous solution using rice straw and its modification. J Sci Eng Res 4(1): 121-129.

37. Sánchez DRG, Martínez MMR, Correa MMA, Saldival CJ, Sánchez MDI, et al. (2017) Síntesis de hidrogeles de quitosano a partir de cáscara de camarón para ensayos de bioadsorción de cobre. Rev Int Contam Ambien 33: 93-98.

38. Kumar R, Bishnoi N, Garima R, Bishnoi K (2008) Biosorption of chromium (VI) from aqueous solution and electroplating wastewater using fungal biomass. Chem Eng J 135(3): 202-208.
39. Li CH, Yu J, Wang D, Li L, Yang X, et al. (2016) Efficient removal of zinc by multi-stress-tolerant yeast Pichia kudriavzevii A16. Bioresour Technol 206: 43-49.

40. Nguyen ML, Ruey Shin J (2015) Modification of cross linked chitosan beads with histidine and Saccharomyces cerevisiae for enhanced Ni (II) biosorption. J Taiwan Inst Chem Eng 56: 96-102.

41. Ruta L, Paraschivescu C, Matache M, Avramescu S, Farcasanu IC (2010) Removing heavy metals from synthetic effluents using "kamikaze" Saccharomyces cerevisiae cells. Appl Microbiol Biotechnol 85(3): 763771.

42. Tobin M J, Cooper DG, Neufeld RJ (1988) The effects of cation competition on metal adsorption by Rhizopus arrhizus biomass. Biotechnol Bioeng 31: 282-286.

43. Vadkertiova R, Slavikova E (2006) Metal tolerance of yeasts isolated from water, soil and plant environments. J Basic Microbiol 46(2): 145152.

44. Ali A, Di G, Mahar A, Ping W, Feng S, Ronghua L, et al. (2017) Mycoremediation of potentially toxic trace elements. a biological tool for soil cleanup: A review. Pedosphere 27(2): 205-222.

45. Beltrán M, Gómez A (2015) Metales pesados (Cd, Cr y Hg) Su impacto en el ambiente y posibles estrategias biotecnológicas para su remediación. Rev 2(2): 82-112.

46. Covarrubias SA, García BJA, Peña CJJ (2015) El papel de los microorganismos en la biorremediación de suelos contaminados con metales pesados. Acta Universitaria 25(3): 40-45.

47. Sala LF, García SI, González JC, Frascaroli MI, Bellú S, et al. (2010) Biosorción para la eliminación de metales pesados en aguas de desecho. Real Sociedad Española Química 106(2): 114-120.

48. Rodríguez IA, Cárdenas González JF, Moctezuma Zárate MG, Rodríguez PA, Martínez Juárez VM (2017) Hexavalent Chromium (VI) Removal by Aspergillus niger. In: "Metal-microbe interactions and bioremediation: Principles and applications for toxic metals". Surajis Das (Ed). CRS Press Book. Taylor\&Francis. Chapter 42, pp. 673-688. 